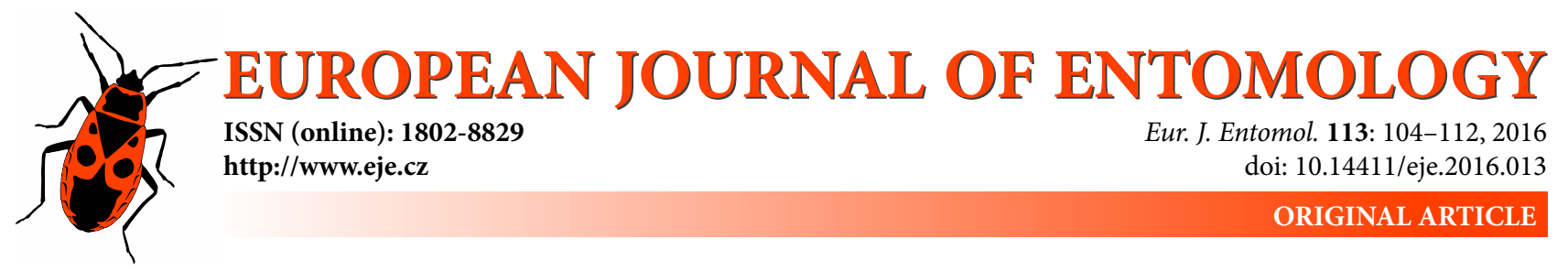

\title{
Climate-induced changes in the phenotypic plasticity of the Heath Fritillary, Melitaea athalia (Lepidoptera: Nymphalidae)
}

\author{
Edit JUHÁSZ ${ }^{1}$, Zsolt VÉGVÁRI ${ }^{2}$, JÁnos P. TÓTH ${ }^{3}$, KATAlin PECSENYE $^{1}$ and Zoltán VARGA ${ }^{1}$ \\ ${ }^{1}$ Department of Evolutionary Zoology and Human Biology, University of Debrecen, Egyetem tér 1, Debrecen 4032, Hungary; \\ e-mails: juhasz.edit@science.unideb.hu,pecskati@gmail.com, varga.zoltan@science.unideb.hu \\ ${ }^{2}$ Department of Conservation Zoology, Hortobágy National Park Directorate, University of Debrecen, Sumen u. 2, Debrecen \\ 4024, Hungary; e-mail: zsolt.vegvari@gmail.com \\ ${ }^{3}$ MTA-DE "Lendület" Behavioural Ecology Research Group, Department of Evolutionary Zoology, University of Debrecen, \\ Egyetem tér 1, Debrecen 4032, Hungary; e-mail: acutiformis@yahoo.com
}

Key words. Lepidoptera, Nymphalidae, Melitaea athalia, butterfly, Carpathian Basin, morphology, Procrustes anova

\begin{abstract}
Recently a large number of studies have reported an increase in the variability in the climate, which affects behavioural and physiological adaptations in a broad range of organisms. Specifically, insects may be especially sensitive to climatic fluctuations, as their physiology and life history traits, like those of other ectotherms, are predominantly affected by environmental factors. Here we aimed to investigate climate-induced changes in several morphometric measures of the Heath Fritillary in North-Eastern Hungary, which is a highly diverse transitional area. During this study we tested the following hypotheses: (i) climate affects genitalia and body size to various degrees (ii) increasing variability in climate induces higher levels of fluctuating asymmetry and variance in all morphological characters. To our knowledge, this study is the first to analyse simultaneously wing size and structure of genitalia of a butterfly in response to variability in climate. Our findings suggest that wing and genital traits may exhibit similar degrees of stability in response to a more variable climate, although the response in terms of forewing size differs from that of other body measurements and the structure of the genitalia. These findings suggest that global climate change may affect lepidopteran body metrics over longer periods of time. Our findings parallel the results of investigations showing that insect morphology might be modified by environmental changes, which is especially the case for those body parts that are phenotypically very variable. However, we found no evidence that increasing variability in climate would induce higher levels of fluctuating asymmetry and greater variability in morphological characters.
\end{abstract}

\section{INTRODUCTION}

Evidence is accumulating that most habitat loss, fragmentation and long-term changes in climate can be attributed to anthropogenic factors (Bellard et al., 2012; Mantyka-Pringle et al., 2012). It is of particular interest to know how different organisms react to changes in climate and weather over long periods of time, especially in terms of their phenology and morphological adaptations. Specifically, insects may be especially sensitive to fluctuations in climate, as their physiology and life history traits are predominantly affected by environmental factors as are those of other small ectotherms (Bale et al., 2002; Wilson et al., 2007). Thus, variation in food availability, predation pressure, temperature, length of the season, photoperiod and humidity can affect the responses of organisms (Hughes et al., 2003, 2007; Karlsson \& Van Dyck, 2005). Heterogeneous environments provide opportunities for exploring the role and limits of natural selection in shaping the response of organisms to environmental change (Pigliucci, 2001).
Characteristics of butterfly wings are widely used as model system for studying development or phenotypic plasticity (Dennis \& Shreeve, 1989; Berwaerts et al., 1998; Hill et al., 1999; Thomas \& Van Dyck, 2006; Talloen et al., 2009; Gibbs et al., 2011). For example, coloration and patterns on the wings of some species of butterflies are known to be very variable and show high levels of phenotypic plasticity in response to different environmental factors (Shapiro, 1976; Brakefield et al., 1996; Brakefield \& French, 1999; Talloen et al., 2009) or food quality (Kooi et al., 1996). Specifically, human-induced habitat fragmentation has been shown to drive morphological modifications (Berwaerts et al., 1998). Furthermore, results of experimental studies support the hypothesis that changes in climate drive morphological characters (Gibbs et al., 2011): Xi et al. (2015) indicate that temperature increase per se and its interaction with the direction of temperature change should be primarily responsible for shifts in body size at different times of the year. Therefore, seasonal patterns in temperature in temperate regions could be of gen- 
eral importance for predicting changes in animal body size in respone to a warmer climate. In contrast, insect genital characteristics differ greatly, even between sibling species, and seem to be only slightly affected by environmental factors (Cesaroni et al., 1994; Dapporto et al., 2009, 2011).

As a result of environmental perturbations, self-regulatory mechanisms might be unable to stabilize development (Van Valen, 1962; Palmer \& Strobeck, 1986, 1992). Fluctuating asymmetry, which consists of small random differences between left and right sides in bilaterally symmetrical structures of organisms, is a widely used measure of developmental instability (Van Valen, 1962; Palmer, 1997). However, there is growing evidence from both experimental and non-experimental studies that fluctuating asymmetry does not consistently predict stress or fitness (Lens et al., 2002; Silva et al., 2009).

Owing to their highly variable morphometric characteristics, members of the genus Melitaea (Lepidoptera: Nymphalidae) provide opportunities for studying the effects of climate change and variability on lepidopteran morphology. In addition, butterflies are particularly well represented in museum collections, thus morphometric studies can also be carried out on both wings and external genitalia of a number of lepidopterans using historical data.

In the present study, we aim to investigate the effects of changes in climate on the (i) wing size and (ii) genital characteristics of the Heath Fritillary butterfly - Melitaea athalia (Rottemburg, 1775), which is a threatened species in Western Europe but not yet endangered in the eastern part of the continent (Van Swaay \& Warren, 1999; Van Swaay et al., 2010). For example, this species is a priority species for butterfly conservation in England, where its phenology and population structure have been studied in detail (Warren, 1987a, b, c, 1991; Hodgson et al., 2009). In contrast, this species occurs in an astonishing variety of ecological situations in Hungary. The main object of the present work is to determine whether climate-induced changes occur in several morphometric measures of this butterfly in the Aggtelek Karst area, which is a highly diverse transitional area where continental, mountain and Mediterranean species co-occur within a limited area (Varga, 1997). In addition, this region has long been considered an important site for entomological studies (Varga \& Szabó, 1997; Nagy et al., 1999; Pecsenye et al., 2007; Árnyas et al., 2009; Bereczki et al., 2011; Bátori et al., 2012a, b), including some on the effect of climate change (Végvári et al., 2014). In our analyses we primarily focused on the relationships between climatic predictors and morphological traits. We choose this approach as relationships between temporal trends in environmental predictors and their effects on morphological metrics is rather complex (Parmesan \& Yohe, 2003) and the absence of temporal trends in morphological traits does not exclude interrelationships between morphometry and climatic proxies.

Our study is based on the following hypotheses. Firstly, high temperatures induce longer larval feeding periods, which results in larger body metrics. Secondly, theory predicts that genitalia measurements are under more con- strained genetic control than body metrics, therefore we expect that changes in temperature will affect genitalia and body measurements differently. Thirdly, we aim to test the hypothesis that with increase in climatic variability there is an increase in fluctuating asymmetry and variance in all morphological characters (Joubert \& Bijlsma, 2010).

\section{MATERIALS AND METHODS}

\section{Climate data}

We obtained meteorological data for 1967-2013 from the nearest meteorological station at Miskolc $\left(48.1^{\circ} \mathrm{N}, 20.4^{\circ} \mathrm{E}\right)$, which is $60 \mathrm{~km}$ from the study site, and the only station for which there is long-term dataset necessary for determining trends in climate (Végvári et al., 2014). To assess temporal patterns in climatic predictors relevant for larval development of the species studied, we calculated (i) mean temperatures in March, April and May (ii) temperature averaged across March to April and March to May (iii) mean seasonal temperatures (iv) precipitation sums for the above periods, which is when the larvae are feeding. To calculate the same metrics for the pre-diapausal and diapausal periods, we repeated these analyses for July and August to February, respectively (Pöyry et al., 2011). Monthly and seasonal means of climatic proxies are widely used in insect studies (Altermatt, 2010a; Gibbs et al., 2011; Mega, 2014). Although climatic parameters may fluctuate strongly within a month, we were interested in the effects of the overall trend in climate. To detect temporal trends in weather proxies, we fitted linear regressions to these variables as a function of years.

\section{Sample collection}

In total, 228 male individuals were analyzed all of which were captured in the Jósvafó area of the Aggtelek Karst region, EastHungary. Specimens were collected between 1967-2013 only in May and June and stored in the collection of the University of Debrecen (Table 1). As only male individuals were available in sufficiently large numbers to carry out the analyses and morphometric traits (measure and shape) showed marked sexual dimorphism, we used only the data for male specimens. Further, to increase the robustness of our results, we removed records for years when less than four individuals were caught.

Table 1. Numbers of specimens caught each year that were used in the morphometric analyses.

\begin{tabular}{ccc}
\hline Year & $\begin{array}{c}\text { Number of specimens for } \\
\text { wing measurements }\end{array}$ & $\begin{array}{c}\text { Number of specimens for } \\
\text { genitalia measurements }\end{array}$ \\
\hline 1967 & 22 & 24 \\
1975 & 7 & 15 \\
1976 & 5 & 8 \\
1981 & 16 & 10 \\
1983 & - & 1 \\
1984 & - & 2 \\
1986 & 1 & 2 \\
1988 & 5 & 6 \\
1999 & 22 & 25 \\
2000 & 12 & 12 \\
2001 & 15 & 26 \\
2007 & 14 & 24 \\
2008 & 21 & 44 \\
2011 & 14 & 15 \\
2012 & 13 & 14 \\
\hline
\end{tabular}



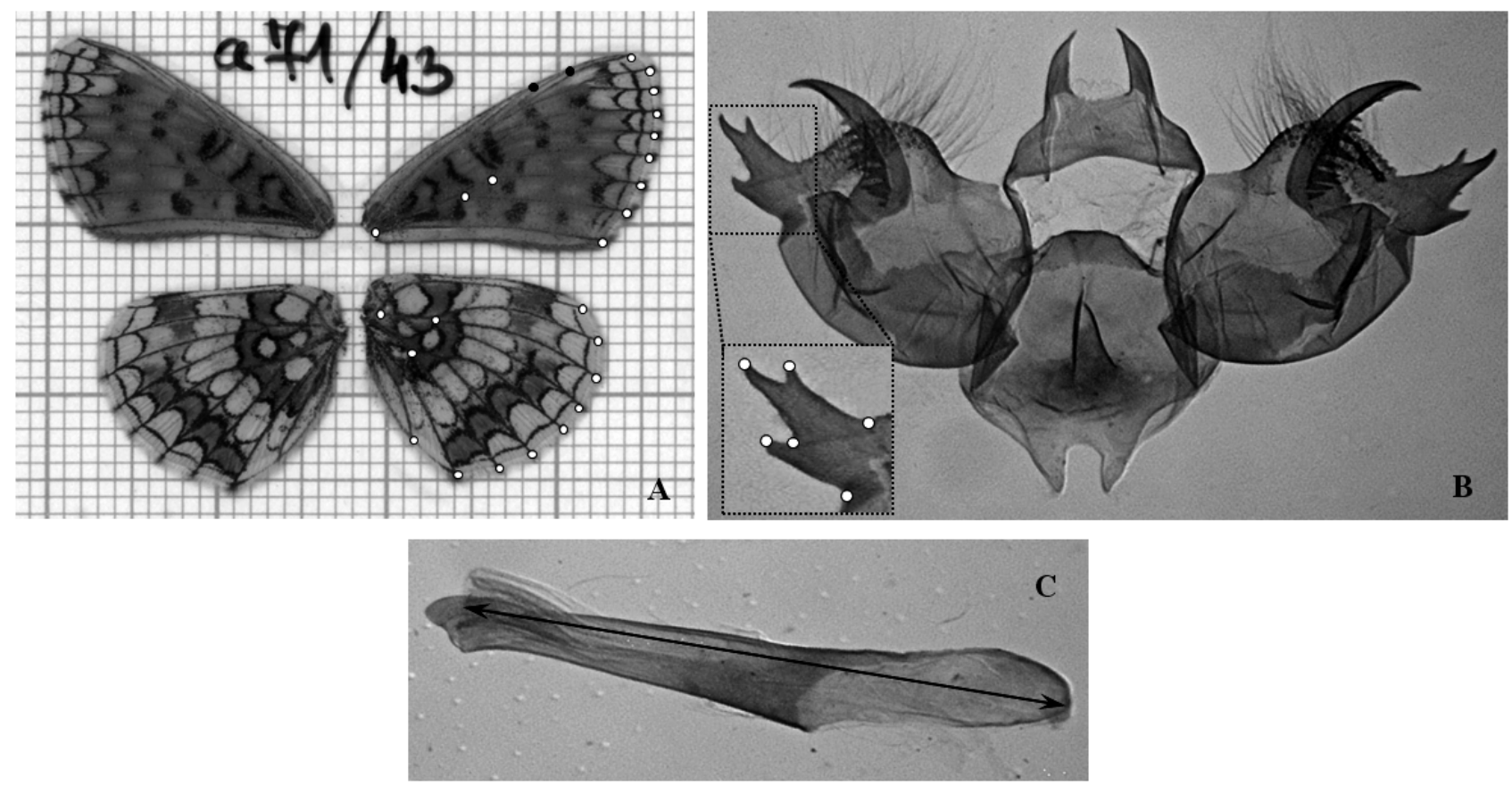

Fig. 1. Features measured on wings and genitalia. Black dots illustrate the two sliding landmarks on the forewing. $A-$ wing; $B-$ external genitalia; $\mathrm{C}$ - aedeagus.

\section{Geometric morphometry}

Male wings were fixed on transparent films and digitalised using Canon CanoScreen 5200F scanner. Landmark-based geometric morphometric analyses were used to quantify the variation in the shape of wing and reveal any asymmetry. Accordingly, we recorded 14 landmarks on the forewing and 12 on the hindwing at characteristic meeting points of veins (Fig. 1A). Landmark points were assigned as interception points of the veins with insignificant topological variability, following the recommendations of Sanzana et al. (2013) and Bereczki et al. (2014).

The preparation procedure of male external genitalia was carried out based on (Bátori, 2012b). Slides were digitalised using an Olympus C-4000 Zoom camera and a Canon stereomicroscope. Landmark-based geometric morphometric analyses were used to quantify the variation in the shape of processus posterior on the valvae. We recorded 6 landmarks at the tips and origin of the main processi (Fig. 1B). In both cases (wing and external genitalia) TpsDig 2.1 was used to digitalise landmarks (Zelditch et al., 2012).

In the following analyses shape and size variables were treated as dependent metrics and calculated across individuals grouped by year-of-catch: (i) degree of bilateral asymmetry of both wings and processus posterior by retrieving the Goodall's F-statistic provided by the component of fluctuating asymmetry as a result of Procrustes ANOVA fitted on shape variation (ii) centroid size of both wings and processus posterior calculated by using Procrustes-transformed coordinates (iii) aedeagus length (henceforth morphometric variables). For geometric morphometry we apply the frequently used centroid size, which is defined as the square root of the summed squared distances of each landmark to the centroid.

\section{Traditional morphometry}

Traditional morphometry was used to detect changes in the length of the aedeagus (Fig. 1C). Length of the aedeagus was measured using the Image J 1.36 program (Kizic \& Borovac, 2001).
Morphometric characteristics of wings and genitalia were chosen from a large set of characters for which the measurement errors were estimated using a series of hierarchical ANOVA. The measurement errors of the characters used in this study accounted for less than $10 \%$ of the total variance.

All measurements were repeated three times on each individual to control for measurement error.

\section{Statistical analyses}

In the first step, we used Procrustes generalized least squares (ProcGLS) to determine the shape of both fore- and hindwings and male genitalia. Procrustes transformation aims to rescale coordinates to unit centroid size and rotate in order to minimize the sum of squared distances among corresponding landmarks. In the case of forewings we included two sliding landmarks to control for position variance of these unfixed reference points, as indicated by Fig. 1A (Adams \& Otárola-Castillo, 2013).

To assess measurement error, the data was subjected to Procrustes ANOVA (Klingenberg \& McIntyre, 1998), which indicate significantly lower levels of measurement error $(<3.0 \%$ on average) than differences between individuals, and between left and right sides of individuals $(\mathrm{p}<0.0001)$ (White \& Searle, 2008).

In the following step we assessed the effect of climatic variables on all morphometric variables by formulating Procrustes full Linear Mixed Models (LMM) including all climate proxies added as fixed factors and individual ID as a random factor.

After model fitting, the relative importance of environmental variables was determined using an information-theoretic modelcomparison, which provides robust measures of climatic responsiveness in in terms of body metrics independent of sample size and is thus a robust estimate of the importance of predictors unbiased by the significance levels of a large number of covariates (Burnham \& Anderson, 2002). This approach, therefore, excludes the possibility of significant relationships emerging from a large set of predictors, since the importance of each predictor is determined by a subset of models with substantial support, based on their information content (Burnham \& Anderson, 2002). The model selection procedure was as follows. First we obtained 
Table 2. Temporal trends in the climatic variables measured based on linear regressions as a function of years. Significant relationships $(p<0.05)$ are indicated in bold.

\begin{tabular}{|c|c|c|c|}
\hline Climatic predictor & Parameter estimate & Adjusted $\mathrm{R}^{2}$ & $p$ \\
\hline \multicolumn{4}{|l|}{ Temperature mean } \\
\hline March & 4.0126 & 0.0593 & 0.0706 \\
\hline April & 3.7312 & 0.1548 & 0.0058 \\
\hline May & 2.2243 & 0.0434 & 0.0985 \\
\hline May to April & 1.1768 & 0.0050 & 0.3771 \\
\hline March to April & 5.5894 & 0.1961 & 0.0019 \\
\hline March to May & 5.5894 & 0.1961 & 0.0019 \\
\hline July & 2.2841 & 0.0511 & 0.0872 \\
\hline August to February & 1.2370 & 0.0072 & 0.2190 \\
\hline \multicolumn{4}{|l|}{ Precipitation totals } \\
\hline March & 0.0055 & 0.0277 & 0.9613 \\
\hline April & 0.1094 & 0.0186 & 0.1975 \\
\hline May & -0.0010 & -0.0270 & 0.9846 \\
\hline Complete life cycle (previous May to April) & -0.0185 & 0.3914 & $<0.0001$ \\
\hline March to April & -0.0169 & 0.3277 & $<0.0001$ \\
\hline March to May & -0.0169 & 0.3277 & $<0.0001$ \\
\hline July & 0.1770 & 0.0223 & 0.1218 \\
\hline August to February & -0.0114 & 0.0212 & 0.8991 \\
\hline
\end{tabular}

the values of Akaike's information criterion corrected for small sample size $\left(\mathrm{AIC}_{\mathrm{c}}\right)$ and the corresponding Akaike weight of each model $(\omega)$. Second, we selected models with substantial support $\left(\Delta_{i}=\mathrm{AIC}_{\mathrm{i}}-\mathrm{AIC}_{\min }<2.0\right)$ and calculated model-averaged parameter estimates $(\beta)$ and unconditional standard errors $\left(\mathrm{SE}_{\mathrm{u}}\right.$; Burnham \& Anderson, 2002) of each variable using the sums of their Akaike weights across all the models containing the given predictor that had substantial support. Akaike differences in the range 0-2 indicate a substantial level of empirical support for a given model, whereas $\Delta_{\mathrm{i}}>7$ implies very weak support (Burnham \& Anderson, 2002).

All statistical analyses were carried out in the $\mathrm{R}$ statistical programming environment (R Development Core Team, 2013), using the specific packages "geomorph" (Adams \& Otárola-Castillo, 2013), "shapes" (Dryden, 2007), "MuMIn" (Barton, 2011) and "nlme" (Pinheiro et al., 2010).

\section{RESULTS}

\section{Climatic patterns}

First we investigated the temporal trends in the predictors of climate change. Spring temperatures increased in all periods: there were significant positive temporal trends in the mean temperatures of April, March to April and March to May $(\mathrm{b}=3.731, \mathrm{p}=0.0058 ; \mathrm{b}=5.589, \mathrm{p}=0.002 ; \mathrm{b}=$ $5.589, p=0.002$, respectively, Table 2 ). Significant negative temporal trends were recorded in the sum of the precipitation from March to May $(b=-0.161, p<0.0001$, Table 2). There were no clear temporal trends in summer, autumn and winter climatic variables, and those recorded over the pre-diapausal and diapausal periods.

\section{Effects of changes in climate on the morphology of wings and genitalia}

In the case of the relationship between forewing centroid size and April mean temperature: forewing size increased with temperature $(\beta=16.446 \pm 2.033$, Table 3 , Fig. 2 , Appendix 1). In contrast, there was no correlation between hindwing centroid size and processus posterior, and climatic predictors in the best supported models fitted to both these metrics. Similarly, aedeagus length was not associated with any of the climatic variables.

Fluctuating asymmetry of both wing measurements and processus posterior was not associated with any of the climatic predictors measured as none of these climatic predictors were supported variables. In addition, there was no correlation between the body metrics measured and climatic parameters recorded in the pre-diapausal and diapausal periods (Table 3, Appendix 1).

\section{DISCUSSION}

Our study provides two main findings. First, wing and genital traits exhibit similar degrees of stability in response to variations in climate, although with contrasting patterns between forewing size and other body measurements and variation in genitalia. Second, our results suggest that glob-

Table 3. Model-averaged parameters calculated across best supported models fitted to centroid size of forewing.

\begin{tabular}{lrrrrr}
\hline Variable & \multicolumn{1}{c}{ B } & \multicolumn{1}{c}{ SEu } & Adjusted SE & Lower Cl & Upper Cl \\
\hline Intercept & 994.014 & 154.199 & 155.451 & 691.295 & 1296.733 \\
Temperature means & & & & & \\
$\quad$ March & -18.131 & 21.697 & 21.724 & -60.710 & 24.449 \\
April & 16.446 & 8.621 & 8.645 & $\mathbf{9 . 1 3 3}$ & $\mathbf{5 1 . 0 3 0}$ \\
$\quad$ March to April & -1.322 & 28.605 & 28.645 & -57.466 & 54.821 \\
$\quad$ Cumulative temperature (March to April) & 0.341 & 0.275 & 0.276 & -0.200 & 0.881 \\
\hline
\end{tabular}




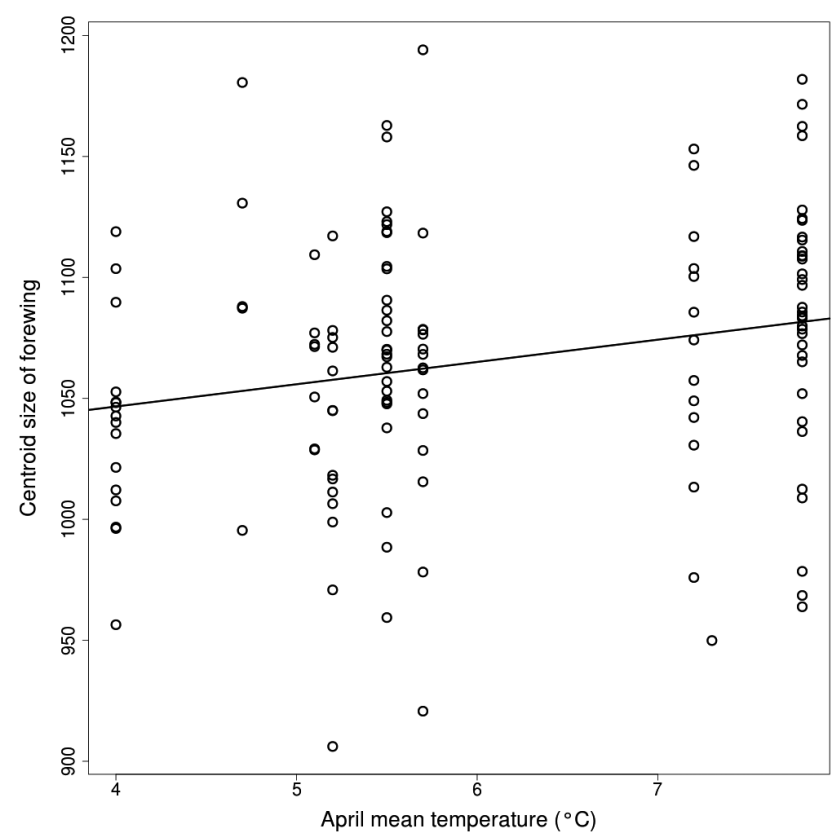

Fig. 2. Centroid size of forewing as a function of April mean temperature.

al changes in climate may affect lepidopteran body metrics over longer periods of time.

Our study is in accordance with others in indicating that insect morphology might be modified by environmental changes, especially in terms of an increased variability in phenotype (Dennis \& Shreeve, 1989; Berwaerts, 1998; Talloen et al., 2009; Gibbs et al., 2011). Indeed, the recent work of Xi et al. (2015) support the hypothesis that there has been changes in morphology resulting from recent changes in climate. However, the regional and taxonomic variance in the degree of climate-induced changes in body metrics is still not yet fully understood (Xi et al., 2015).

Our finding that some characteristics of lepidopteran wings vary with the season and possibly with changes in climate implies that they might be an important part of their adaptation to changes in their microclimates, which is confirmed by a recent experimental study (Gibbs et al., 2011). Changes in the shape and size of wings affect thermoregulation in ectotherms (Willmer, 1991; De Keyser et al., 2015). However, relationships between thermal preferences and body metrics are less clear in ectotherms than endotherms, as a recent study demonstrates that there is no evidence for Bergmann's rule applying to insects (Shelomi, 2012). In contrast, increase in body size in lepidopterans induced by high temperatures is predicted by various hypotheses. Firstly, warmer and earlier springs may lead to the larvae spending more time feeding, which result in increased forewing length (Mega, 2014). Secondly, larval size might be indirectly affected by physical characteristics of the food (Dennis, 1991; García-Barros, 2000). Specifically, warm springs might induce earlier and faster development of food plants, which results in an early abundance of food for the larvae, which thus grow larger. However, as the effects of seasonal changes in climate on larval development via the effect on the food plants of the change in climate are still unknown, further studies on the cascading effects of climatic processes on trophic networks are needed (García-Barros, 2000).

Due to this complexity the relationships between temporal trends in climatic predictors and their effects on morphometry is not straightforward (Parmesan \& Yohe, 2003). This might account for why we did not record temporal trends in various morphological traits that are known to be affected by changes in climate.

The greater degree of plasticity in the size of the forewing than of the hindwing in response to changes in temperature is in line with the results of an experimental study that indicates the asymmetric resistance to aerodynamic twisting of the broad forewings of butterflies is a consequence of the curved section of the leading edge (Wootton, 1993). Another investigation indicates that hindwings are not necessary for flight but essential for the execution of evasive flight in butterflies (Jantzen \& Eisner, 2008). Thus, the asymmetrical aerodynamic behaviour of the fore- and hindwings might require different allocations of a resource, as these organs compete for a haemolymph-borne resource, such as a nutrient or growth factor (Klingenberg \& Nijhout, 1998).

Our finding that forewing size was associated with the temperatures during larval development in spring indicates that environmental conditions experienced by caterpillars can affect adult morphology. Indeed, recent studies have shown that environmental conditions during a specific period in an individual's life cycle are reflected in fitness during the breeding season. For instance, a low availability of food during the pre-hibernation period might result in reduced breeding success (Boggs, 2009; Harrison et al., 2011). This result parallels that of a number of studies that demonstrate that for a large number of lepidopterans warm springs accelerate larval development indirectly by advancing food plant phenology (Altermatt, 2010b). As the species studied is an oligophagous specialist feeding on plants that contain iridoid-glycosides, we assume that larval phenology of $M$. athalia is less constrained by the responsiveness of its food plants to changes in climate than lepidopterans that are more host specific (Warren, 1987a). However, as the effectiveness of insect digestion depends on temporal changes in temperature (Bale et al., 2002), studies on food plant utilisation and nutrient cycle of host specific species is required.

Although the mechanisms underlying how the climatic conditions experienced early on in development can affect later stages of development are not fully understood, possible processes include phenotypic plasticity, microevolutionary processes and epigenetic modifications of morphological traits (Scaven \& Rafferty, 2013). More specifically, the variation in body size, growth rate and development time of dung flies remained the same after several generations of artificial selection for body size, indicating that the largest fraction of the phenotypic variance is heritable or environmentally induced plasticity (Blanckerhorn et al., 2009). Similarly, another experimental study shows that morphological alterations might be linked to thermal con- 
ditions (Gibbs et al., 2011; Harper, 2011). Such a mechanism might account for the rapid changes in morphological characters in response to changes in climate recorded for M. athalia in this study.

In contrast to forewing morphology, measurements of all other body parts, including hindwing, size of the processus posterior and length of the aedeagus, were not associated over the period of this study with any of the climatic predictors measured, probably because of their stricter genetic control (reviewed in e.g. Simmons, 2014). In addition, forewing dimensions are robust predictors of body size (Miller, 1977; Noriyuki et al., 2010; Mega, 2014) and are associated with changes in climate (Mega, 2014; Xi et al., 2015).

Changes in climate did not affect fluctuating asymmetry and the variance in the morphology of both wings and genitalia. Our study did not reveal an increase in fluctuating asymmetry with increase in the unfavourableness of the environment. This finding parallels an investigation on fruit flies carried out by Joubert \& Bijlsma (2010), which indicates that the effects of temperature on fluctuating asymmetry is far from unequivocal and might result from a combination of the effects associated with several different environmental predictors.

The robustness of our results is indicated by the fact that we were able to detect biologically relevant trends as a function of macroclimatic conditions in spite of the fact that microclimate has more direct effects on insect development than macroclimate.

In summary, our study highlights the importance of responsiveness of various aspects wing morphology of a lepidopteran that is decreasing throughout Europe to changes in climate, which might be important in determining its ability to adapt to an acceleration in climate change.

ACKNOWLEDGEMENTS. This research was supported by the European Union and the State of Hungary, co-financed by the European Social Fund within the framework of TÁMOP-4.2.4.A 2-11/1-2012-0001 "National Excellence Program". Many thanks go to S. Szabó for assisting in field collections. The support of the nature conservation authorities of Hungary was greatly appreciated.

\section{REFERENCES}

Adams D.C. \& OtÁRola-CASTILlo E. 2013: geomorph: an R package for the collection and analysis of geometric morphometric shape data. - Meth. Ecol. Evol. 4: 393-399.

Altermatt F. 2010a: Climatic warming increases voltinism in European butterflies and moths. - Proc. R. Soc. Lond. 277: 1281-1287.

Altermatt F. 2010b: Tell me what you eat and I'll tell you when you fly: diet can predict phenological changes in response to climate change. - Ecol. Lett. 13: 1475-1484.

Árnyas E., Bereczki J., Tóth A., Varga K., Pecsenye K., TartalLY A. \& VARGA Z. 2009: Oviposition preferences of Maculinea alcon as influenced by aphid (Aphis gentianae) and fungal (Puccinia gentianae) infestation of larval host plants. - Ecol. Entomol. 34: 90-97.

Bale J.S., Masters G.J., Hodkinson I.D., Awmack C., Bezemer T.M., Brown V.K. \& WhitTAKER J.B. 2002: Herbivory in global climate change research: direct effects of rising temperature on insect herbivores. - Glob. Chang. Biol. 8: 1-16.

Bátori E., Pecsenye K., Bereczki J. \& Varga Z. 2012a: Patterns of genetic and taxonomic differentiation in three Melitaea (subg. Mellicta) species (Lepidoptera, Nymphalidae, Nymphalinae). - J. Insect Conserv. 16: 647-656.

Bátori E., Pecsenye K., Tóth J.P. \& Varga Z. 2012b: Patterns of genetic and morphometric differentiation in Melitaea (Mellicta) athalia (Lepidoptera: Nymphalidae). - Biol. J. Linn. Soc. 107: 398-413.

BARTON K. 2011: MuMIn: Multi-Model Inference. R Package Ver. 1.0.0. R Foundation for Statistical Computing, Vienna, http:// CRAN.R-project.org $/$ package $=$ MuMIn.

Bellard C., Bertelsmeier C., Leadley P., Thuiller W. \& CourCHAMP F. 2012: Impacts of climate change on the future of biodiversity. - Ecol. Lett. 15: 365-377.

Bereczki J., Tóth J.P., Tóth A., Bátori E., Pecsenye K. \& Varga Z. 2011: The genetic structure of phenologically differentiated Large Blue (Maculinea arion) populations (Lepidoptera: Lycaenidae) in the Carpathian Basin. - Eur. J. Entomol. 108: 519-527.

Berwaerts K., Van Dyck H., Van Dongen S. \& Matthysen E. 1998: Morphological and genetic variation in the speckled wood butterfly (Pararge aegeria L.) among differently fragmented landscapes. - Neth. J. Zool. 48: 241-253.

BLANCKENHORN W.U., WhitMAN D.W. \& ANANTHAKRISHNAN T.N. 2009: Causes and consequences of phenotypic plasticity in body size: the case of the yellow dung fly Scathophaga stercoraria (Diptera: Scathophagidae). In Whitman D.W. \& Ananthakrishnan T.N. (eds): Phenotypic Plasticity of Insects: Mechanisms and Consequences. Science Publishers, Enfield, NH, pp. 369-422.

BogGs C.L. 2009: Understanding insect life histories and senescence through a resource allocation lens. - Funct. Ecol. 23: 27-37.

BRakefield P.M. \& French V. 1999: Butterfly wings: the evolution of development of colour patterns. - BioEssay 21: 391401.

Brakefield P.M., Gates J., Keys D., Kesbeke F., Wijngaarden P. J., Monteiro A. \& Carroll S.B. 1996: Development, plasticity and evolution of butterfly eyespot patterns. - Nature 384: 236-242.

Burnham K.P. \& Anderson D.R. 2002: Model Selection and Multimodel Inference: A Practical Information-Theoretic Approach. Springer, New York, 488 pp.

Cesaroni D., Lucarelli M., Allori P., Russo F. \& Sbordoni V. 1994: Patterns of evolution and multidimensional systematics in graylings (Lepidoptera: Hipparchia). — Biol. J. Linn. Soc. 52: 101-119.

Dapporto L., Bruschini C., Baracchi D., Cini A., Gayubo S.F., GonzÁlez J.A. \& Dennis R.L.H. 2009: Phylogeography and counter-intuitive inferences in island biogeography: evidence from morphometric markers in the mobile butterfly Maniola jurtina (Linnaeus) (Lepidoptera, Nymphalidae). - Biol. J. Linn. Soc. 98: 677-692.

Dapporto L., Habel J.C., Dennis R.L. \& Schmitt T. 2011: The biogeography of the western Mediterranean: elucidating contradictory distribution patterns of differentiation in Maniola jurtina (Lepidoptera: Nymphalidae). — Biol. J. Linn. Soc. 103: 571-577.

De Keyser R., Breuker C.J., Hails R.S., Dennis R.L. \& Shreeve T.G. 2015: Why small is beautiful: Wing colour is free from thermoregulatory constraint in the small lycaenid butterfly, Polyommatus icarus. — PLoS ONE 10(4): e0122623, 13 pp. 
DenNis R.L.H. \& Shreeve T.G. 1989: Butterfly wing morphology variation in the British Isles: the influence of climate, behavioural posture and the hostplant-habitat. - Biol. J. Linn. Soc. 38: $323-348$.

Dennis R.L.H. \& Shreeve T.G. 1991: Climatic change and the British butterfly fauna: opportunities and constraints. - Biol. Conserv. 55: 1-16.

Dryden I.L. 2007: Shapes: Statistical Shape Analysis. R Package Ver. 1.1-1. http://www.maths.nottingham.ac.uk/ ild/shapes

García-BARros E. 2000: Body size, egg size, and their interspecific relationships with ecological and life history traits in butterflies (Lepidoptera: Papilionoidea, Hesperioidea). — Biol. J. Linn. Soc. 70: 251-284.

GibBs M., Wiklund C. \& VAn Dyck H. 2011: Temperature, rainfall and butterfly morphology: does life history theory match the observed pattern? - Ecography 34: 336-344.

HARPER M.N.E. 2011: Impacts of Climate Driven Range Changes on the Genetics and Morphology of Butterflies. PhD Thesis, University of York, $120 \mathrm{pp}$.

Harrison X.A., Blount J.D., Inger R., Norris D.R. \& Bearhop S. 2011: Carry-over effects as drivers of fitness differences in animals. - J. Anim. Ecol. 80: 4-18.

Hill J.K., Thomas C.D. \& Blakeley D.S. 1999: Evolution of flight morphology in a butterfly that has recently expanded its geographic range. - Oecologia 121: 165-170.

Hodgson J.A., Moilanen A., Bourn N.A.D., Bulman C.R. \& Thomas C.D. 2009: Managing successional species: Modelling the dependence of heath fritillary populations on the spatial distribution of woodland management. - Biol. Conserv. 142: 2743-2751

Hughes C.L., Hill J.K. \& Dytham C. 2003: Evolutionary tradeoffs between reproduction and dispersal in populations at expanding range boundaries. - Proc. R. Soc. Lond. 270: $147-$ 150.

Hughes C.L., Dytham C. \& Hill J.K. 2007: Modelling and analysing evolution of dispersal in populations at expanding range boundaries. - Ecol. Entomol. 32: 437-445.

JANTZEN B. \& EISNER T. 2008: Hindwings are unnecessary for flight but essential for execution of normal evasive flight in Lepidoptera. - Proc. Natl. Acad. Sci. U.S.A. 105: 1663616640.

Joubert D. \& BiJLsma R. 2010: Interplay between habitat fragmentation and climate change: inbreeding affects the response to thermal stress in Drosophila melanogaster. - Clim. Res. 43: 53-57.

KARLSSON B. \& VAN DyCK H. 2005: Does habitat fragmentation affect temperature-related life-history traits? A laboratory test with a woodland butterfly. - Proc. R. Soc. Lond. 272: $1257-$ 1263.

Kizic M. \& Borovac M. 2001: ImageJ: Image Processing and Analysis in Java. http://rsb.info.nih.gov/ij/docs/pdfs/imagejgui.pdf

Klingenberg C.P. \& McIntyre G.S. 1998: Geometric morphometrics of developmental instability: analysing patterns of fluctuating asymmetry with Procrustes methods. - Evolution 52: $1363-1375$

Klingenberg C.P. \& NiJhout H.F. 1998: Competition among growing organs and developmental control of morphological asymmetry. — Proc. R. Soc. Lond. 265: 1135-1139.

Kool R.E., Brakefield P.M. \& Rossie W.E.M.-TH. 1996: Effects of food plant on phenotypic plasticity in the tropical butterfly Bicyclus anynana. - Entomol. Exp. Appl. 80: 149-151.

Lens U.C., Dongen S., Kark S. \& Matthysen E. 2002: Fluctuating asymmetry as an indicator of fitness: can we bridge the gap between studies? - Biol. Rev. 77: 27-38.
Mantyka-Pringle C.S., Martin T.G. \& Rhodes J.R. 2012: Interactions between climate and habitat loss effects on biodiversity: a systematic review and meta-analysis. - Glob. Chang. Biol. 18: 1239-1252.

Mega N.O. 2014: The adult body size variation of Dryas iulia (Lepidoptera, Nymphalidae, Heliconiinae) in different populations is more influenced by temperature variation than by host-plant availability during the seasons. - Entomol. Sci. 17: 376-387.

MiLLER W.E. 1977: Wing measure as a size index in Lepidoptera: the family Olethreutidae. - Ann. Entomol. Soc. Am. 70: 253256.

NAGY B., RÁcz I. \& VARGa Z. 1999: The orthopteroid insect fauna of the Aggtelek karst region (NE Hungary) referring to zoogeography and nature conservation. In Mahunka S. (ed.): The Fauna of the Aggtelek National Park. Akadémiai Kiadó, Budapest, pp. 83-102.

NoriYUKI S., KISHI S. \& NishidA T. 2010: Seasonal variation of egg size and shape in Ypthima multistriata (Lepidoptera: Satyridae) in relation to maternal body size as a morphological constraint. - Ann. Entomol. Soc. Am. 103: 580-584.

Palmer A.R. \& Strobeck C. 1986: Fluctuating asymmetry: measurement, analysis, patterns. - Annu. Rev. Ecol. Syst. 17: 391-421.

Palmer A.R. \& Strobeck C. 1992: Fluctuating asymmetry as a measure of developmental stability: implications of non-normal distributions and power of statistical tests. - Acta Zool. Fenn. 191: 57-72.

Palmer A.R. \& Strobeck C. 1997: Fluctuating asymmetry and developmental stability: heritability of observable variation vs. heritability of inferred cause. - J. Evol. Biol. 10: 39-49.

Parmesan C. \& Yohe G. 2003: A globally coherent fingerprint of climate change impacts across natural systems. - Nature 421: $37-42$.

Pecsenye K., Bereczki J., Szilagyi M. \& Varga Z. 2007: High level of genetic variation in Aricia artaxerxes issekutzi (Lycaenidae) populations in Northern Hungary. - Nota Lepid. 30: 225-234.

Pigliucci M. 2001: Phenotypic Plasticity: Beyond Nature and Nurture. John Hopkins University Press, Baltimore, 328 pp.

Pinheiro J., Bates D., DebRoy S. \& Sarkar D. 2010: nlme: Linear and Nonlinear Mixed Effects Models. R Package Ver. 3.196. R Foundation for Statistical Computing, Vienna.

Pöyry J., Leinonen R., Söderman G., Nieminen M., Heikkinen R.K. \& CARTER T.R. 2011: Climate-induced increase of moth multivoltinism in boreal regions. - Glob. Ecol. Biogeogr. 20: 289-298.

R Development Core Team 2013: R: A Language and Environment for Statistical Computing. R Foundation for Statistical Computing, Vienna, http://www.R-project.org

Sanzana M.J., Parra L.E., Sepúlveda-ZúNíga E. \& Benítez H.A. 2013: Latitudinal gradient effect on the wing geometry of Auca coctei (Guérin) (Lepidoptera, Nymphalidae). - Rev. Bras. Entomol. 57: 411-416.

SCAVEN V.L. \& Rafferty N.E. 2013: Physiological effects of climate warming on flowering plants and insect pollinators and potential consequences for their interactions. - Curr. Zool. 59: 418-426.

Shelomi M. 2012: Where are we now? Bergmann's rule sensu lato in insects. - Am. Nat. 180: 511-519.

Simmons L.W. 2014: Sexual selection and genital evolution. Austr. Entomol. 53: 1-17.

ShapIRo A.M. 1976: Seasonal polyphenism. - Evol. Biol. 9: 259-333. 
Silva M.C., Lomônaco C., Augusto S.C. \& Kerr W.E. 2009: Climatic and anthropic influence on size and fluctuating asymmetry of Euglossine bees (Hymenoptera, Apidae) in a semideciduous seasonal forest reserve. - Genet. Mol. Res. 8: 730-737.

Talloen W., Van Dongen S., Van Dyck H. \& Lens L. 2009: Environmental stress and quantitative genetic variation in butterfly wing characteristics. - Evol. Ecol. 23: 473-485.

Thоmas M. \& VAn Dyck H. 2006: Landscape structure and phenotypic plasticity in flight morphology in the butterfly Pararge aegeria. - Oikos 113: 226-232.

Xi X., Wu X., Nylin S. \& Sun S. 2015: Body size response to warming: time of the season matters in a tephritid fly. Oikos doi: 10.1111/oik.02521

Van SwaAy C. \& Warren M. 1999: Red Data book of European Butterflies (Rhopalocera). Council of Europe, Strasbourg, 259 pp.

Van Swahy C., Cuttelod A., Collins S., Maes D., Munguira M. L., Sasic M., Settele J., Verovnik R., Verstrael T., Warren M., Wiemers M. \& Wynhoff I. 2010: European Red List of Butterflies. Publications Office of the European Union, Luxembourg, $\mathrm{x}+47 \mathrm{pp}$.

VAN VALEN L. 1962: A study of fluctuating asymmetry. — Evolution 16: 125-142.

VARGA Z. 1997: Biogeographical outline of the invertebrate fauna of the Aggtelek karst and surrounding areas. In Tóth E. \& Horváth R. (eds): Research in Aggtelek National Park and Biospherre Reserve. Proceedings of the Conference, Vol. 2. Aggtelek National Park Directorate, Aggtelek, pp. 87-94.

VARGA Z. \& SZABÓ S. 1997: Changes in species composition and abundance of Lepidoptera in the Aggtelek karst. In Tóth E. \& Horváth R. (eds): Research in Aggtelek National Park and Biospherre Reserve. Proceedings of the Conference, Vol. 2. Aggtelek National Park Directorate, Aggtelek, pp. 137-142.
WARREN M.S. 1987a: The ecology and conservation of the heath fritillary butterfly, Mellicta athalia. I. Host selection and phenology. - J. Appl. Ecol. 24: 467-482.

WARREN M.S. 1987b: The ecology and conservation of the heath fritillary butterfly, Mellicta athalia. II. Adult population structure and mobility. - J. Appl. Ecol. 24: 483-498.

WARREN M.S. 1987c: The ecology and conservation of the heath fritillary butterfly, Mellicta athalia. III. Population dynamics and the effect of habitat management. - J. Appl. Ecol. 24: 499-513.

WARREN M.S. 1991: The succesful conservation of an endangered species the heath fritillary butterfly Mellicta athalia, in Britain. - Biol. Conserv. 55: 37-56.

Végvári Z., Juhász E., Tóth J.P., Barta Z., Boldogh S., Szabó S. \& VARGA Z. 2014: Hibernation stage predicts climatic responsiveness in noctuid moths. - Oikos 124: 235-242.

White T.A. \& Searle J.B. 2008: Mandible asymmetry and genetic diversity in island populations of the common shrew, Sorex araneus. - J. Evol. Biol. 21: 636-641.

WiLLMER P. 1991: Thermal biology and mate acquisition in ectotherms. - Trends Ecol. Evol. 6: 396-399.

Wilson R.J., Davies Z.G. \& Thomas C.D. 2007: Insects and climate change: processes, patterns and implications for conservation. - Symp. R. Entomol. Soc. Lond. 23: 245-279.

WootTon R.J. 1993: Leading edge section and asymmetric twisting in the wings of flying butterflies (Insecta, Papilionoidea). -J. Exp. Biol. 180: 105-117.

Zelditch M.L., Swiderski D.L. \& Sheets H.D. 2012: Geometric Morphometrics for Biologists: A Primer. Elsevier Academic Press, New York, London, 437 pp.

Received August 7, 2015; revised and accepted October 12, 2015 Published online January 14, 2016 
Appendix 1. Table of full model selection of GLM-s fitted to forewing centroid size as a function of climatic variables.

\begin{tabular}{|c|c|c|c|c|c|c|c|c|c|c|c|c|c|}
\hline Model ID & Intercept & $\begin{array}{c}\text { Annual } \\
\text { precipitation }\end{array}$ & $\begin{array}{l}\text { April mean } \\
\text { temperature }\end{array}$ & $\begin{array}{l}\text { March mean } \\
\text { temperature }\end{array}$ & $\begin{array}{l}\text { March-April } \\
\text { mean temp. c }\end{array}$ & $\begin{array}{c}\text { March-April } \\
\text { cumulative temp. }\end{array}$ & $\begin{array}{l}\text { August-February } \\
\text { mean temp. }\end{array}$ & $\begin{array}{l}\text { July mean } \\
\text { temperature }\end{array}$ & df & logLik & $\mathrm{AICc}$ & $\triangle \mathrm{AICc}$ & weight \\
\hline $\begin{array}{r}60 \\
124\end{array}$ & $\begin{array}{l}276893.45 \\
287765.37\end{array}$ & & $\begin{array}{r}10.118 \\
28.29\end{array}$ & $\begin{array}{r}-26.35 \\
-2.75\end{array}$ & $\begin{array}{r}7.63 \\
-18.07\end{array}$ & 0.34 & $\begin{array}{l}-24637.54 \\
-24866.74\end{array}$ & $\begin{array}{l}-196.58 \\
-527.39\end{array}$ & $\begin{array}{l}8 \\
9\end{array}$ & $\begin{array}{l}-2960.13 \\
-2959.73\end{array}$ & $\begin{array}{l}5932.37 \\
5933.63\end{array}$ & $\begin{array}{r}0 \\
1.25\end{array}$ & $\begin{array}{l}0.5721 \\
0.3058\end{array}$ \\
\hline $\begin{array}{l}28 \\
52\end{array}$ & $\begin{array}{l}2825244.66 \\
274728.47\end{array}$ & & 14.20 & $\begin{array}{l}-36.29 \\
-21.82\end{array}$ & 25.12 & 027 & $\begin{array}{l}-24451.46 \\
-25123.53\end{array}$ & $\begin{array}{r}-501.78 \\
99.63 \\
\end{array}$ & $\begin{array}{l}7 \\
7\end{array}$ & $\begin{array}{l}-2963.90 \\
-2964.23\end{array}$ & $\begin{array}{l}5937.89 \\
5938.54\end{array}$ & $\begin{array}{l}5.52 \\
6.16\end{array}$ & $\begin{array}{l}0.0362 \\
0.0262\end{array}$ \\
\hline $\begin{array}{l}44 \\
64 \\
92\end{array}$ & $\begin{array}{l}27201.35 \\
275363.68\end{array}$ & 0.015 & $\begin{array}{l}3.36 \\
9.70 \\
1720\end{array}$ & $\begin{array}{l}-20.64 \\
-16.15\end{array}$ & $\begin{array}{r}-21.40 \\
10.46\end{array}$ & 0.31 & $\begin{array}{l}-2434.196 \\
-2443664\end{array}$ & $\begin{array}{r}-94.08 \\
-130.74 \\
-48.07\end{array}$ & $\begin{array}{l}r \\
9 \\
8\end{array}$ & $\begin{array}{l}-2963.84 \\
-2962.92 \\
-296425\end{array}$ & $\begin{array}{l}5940.00 \\
5940 \\
5\end{array}$ & $\begin{array}{l}7.42 \\
7.62 \\
8.25\end{array}$ & $\begin{array}{l}0.0140 \\
0.0126\end{array}$ \\
\hline $\begin{array}{l}108 \\
128\end{array}$ & $\begin{array}{l}235930.36 \\
260075.76\end{array}$ & 0.001 & $\begin{array}{l}29.20 \\
27.20\end{array}$ & $\begin{array}{r}-10.15 \\
-3.56\end{array}$ & $\begin{array}{l}-29.62 \\
-16.32\end{array}$ & $\begin{array}{l}0.23 \\
0.32\end{array}$ & $\begin{array}{l}-24830.04 \\
-24092.87 \\
-24096.01\end{array}$ & $\begin{array}{r}1206.10 \\
240.70\end{array}$ & $\begin{array}{r}8 \\
8 \\
10\end{array}$ & $\begin{array}{l}-2964.25 \\
-2965.32 \\
-2962.57\end{array}$ & $\begin{array}{l}5940.72 \\
5941.35\end{array}$ & $\begin{array}{l}8.35 \\
8.35 \\
8.98\end{array}$ & $\begin{array}{l}0.0088 \\
0.0064\end{array}$ \\
\hline $\begin{array}{r}116 \\
56 \\
48\end{array}$ & $\begin{array}{l}265223.69 \\
272986.35 \\
27068069\end{array}$ & $\begin{array}{l}0.015 \\
0.014\end{array}$ & & $\begin{array}{l}-35.68 \\
-30.00 \\
-14.86\end{array}$ & $\begin{array}{l}25.73 \\
27.28\end{array}$ & 0.0 & $\begin{array}{l}-24953.18 \\
-24929.76 \\
-23944.81\end{array}$ & $\begin{array}{r}404.39 \\
82.28 \\
-249.40\end{array}$ & $\begin{array}{l}8 \\
8 \\
8\end{array}$ & $\begin{array}{l}-2964.68 \\
-2966.67 \\
-2967.07\end{array}$ & $\begin{array}{l}5941.48 \\
5945.46 \\
5946.27\end{array}$ & $\begin{array}{r}9.10 \\
13.09 \\
13.89\end{array}$ & $\begin{array}{l}0.0060 \\
0.0008 \\
0.0005\end{array}$ \\
\hline $\begin{array}{r}48 \\
112 \\
32\end{array}$ & $\begin{array}{l}232489.42 \\
252703.67\end{array}$ & $\begin{array}{l}0.014 \\
0.022 \\
0.000\end{array}$ & $\begin{array}{l}15.23 \\
22.40 \\
30.36\end{array}$ & & $\begin{array}{l}-13.34 \\
-21.40\end{array}$ & 0.37 & $\begin{array}{l}-249411.81 \\
-24211.85 \\
-23691.66\end{array}$ & $\begin{array}{r}-44.40 \\
1396.09 \\
355.63\end{array}$ & $\begin{array}{l}8 \\
9 \\
8\end{array}$ & $\begin{array}{l}-2967.44 \\
-2966.81\end{array}$ & $\begin{array}{l}5946.21 \\
5947.01 \\
5947.79\end{array}$ & $\begin{array}{l}13.64 \\
15.41\end{array}$ & $\begin{array}{l}0.0005 \\
0.0004 \\
0.0003\end{array}$ \\
\hline $\begin{array}{r}120 \\
76\end{array}$ & $\begin{array}{l}291552.97 \\
262220.41\end{array}$ & $\begin{array}{l}0.018 \\
0.008\end{array}$ & 17.14 & $\begin{array}{l}-30.04 \\
-13.55\end{array}$ & 26.60 & $\begin{array}{r}-0.06 \\
0.18\end{array}$ & $\begin{array}{l}-25142.27 \\
-25635.24\end{array}$ & $\begin{array}{r}-566.37 \\
826.34\end{array}$ & $\begin{array}{l}9 \\
7\end{array}$ & $\begin{array}{l}-2967.30 \\
-2967.30\end{array}$ & $\begin{array}{l}5948.75 \\
5948.77\end{array}$ & $\begin{array}{l}16.38 \\
16.40\end{array}$ & $\begin{array}{l}0.0002 \\
0.0002\end{array}$ \\
\hline $\begin{array}{l}96 \\
16\end{array}$ & 271433.33 & 0.032 & $\begin{array}{l}15.85 \\
0.75\end{array}$ & & & $0.5+2-3$ & $\begin{array}{l}-24335.99 \\
-24253.50\end{array}$ & $\begin{array}{r}28.86 \\
-147.88\end{array}$ & $\frac{9}{7}$ & $\begin{array}{l}-2969.39 \\
-2971.46\end{array}$ & $\begin{array}{l}5948.87 \\
5953.00\end{array}$ & $\begin{array}{l}16.50 \\
20.62\end{array}$ & $\begin{array}{c}0.0001 \\
0\end{array}$ \\
\hline $\begin{array}{l}58 \\
80\end{array}$ & $\begin{array}{l}27303.77 \\
255573.42\end{array}$ & 0.022 & 17.90 & & & 0.24 & $\begin{array}{l}-24794.34 \\
-24814.08\end{array}$ & 731.74 & $\begin{array}{l}5 \\
8\end{array}$ & $\begin{array}{l}-2971.47 \\
-2974.39\end{array}$ & $\begin{array}{l}5955.06 \\
5956.83\end{array}$ & $\begin{array}{l}22.69 \\
24.45\end{array}$ & 0 \\
\hline $\begin{array}{r}59 \\
122\end{array}$ & $\begin{array}{l}-21006.61 \\
274556.33\end{array}$ & 0.043 & & -21.62 & 20.95 & -0.26 & -24864.54 & 878.91 & $\begin{array}{l}7 \\
8\end{array}$ & $\begin{array}{l}-2974.10 \\
-2974.18\end{array}$ & $\begin{array}{l}5958.29 \\
5958.45\end{array}$ & $\begin{array}{l}25.92 \\
26.08\end{array}$ & $\begin{array}{l}0 \\
0\end{array}$ \\
\hline $\begin{array}{r}123 \\
20\end{array}$ & $\begin{array}{l}-21457.38 \\
340179.25\end{array}$ & 0.045 & & & $\begin{array}{r}4.79 \\
20.33\end{array}$ & -0.05 & -27718.93 & $\begin{array}{r}900.15 \\
-1367.33\end{array}$ & $\begin{array}{l}8 \\
6\end{array}$ & $\begin{array}{l}-2976.62 \\
-2974.79\end{array}$ & $\begin{array}{l}5961.30 \\
5961.70\end{array}$ & $\begin{array}{l}28.93 \\
29.32\end{array}$ & $\begin{array}{l}0 \\
0 \\
0\end{array}$ \\
\hline $\begin{array}{l}84 \\
40\end{array}$ & $\begin{array}{l}328369.03 \\
286761.43\end{array}$ & -0.006 & & -16.37 & & 0.31 & $\begin{array}{l}-26248.70 \\
-26183.13\end{array}$ & $\begin{array}{r}-1540.07 \\
82.70\end{array}$ & 7 & $\begin{array}{l}-2975.98 \\
-2977.58\end{array}$ & $\begin{array}{l}5962.05 \\
5965.24\end{array}$ & $\begin{array}{l}29.67 \\
32.87\end{array}$ & $\begin{array}{l}0 \\
0\end{array}$ \\
\hline $\begin{array}{l}51 \\
56\end{array}$ & $\begin{array}{l}278267.08 \\
274098.93\end{array}$ & 0.010 & & -18.29 & & $\begin{array}{r}-0.32 \\
0.06\end{array}$ & $\begin{array}{l}-25218.79 \\
-24825.89\end{array}$ & 121.09 & $\begin{array}{l}0 \\
6 \\
6\end{array}$ & $\begin{array}{l}-2977.10 \\
-2980.64\end{array}$ & $\begin{array}{l}5966.23 \\
5969.34\end{array}$ & $\begin{array}{l}33.80 \\
36.97 \\
36\end{array}$ & $\begin{array}{l}0 \\
0 \\
0\end{array}$ \\
\hline $\begin{array}{l}27 \\
36\end{array}$ & $\begin{array}{l}-14862.00 \\
318954.41\end{array}$ & $\begin{array}{l}0.014 \\
0.029\end{array}$ & & & & -0.27 & -27233.03 & $\begin{array}{r}635.04 \\
-734.93\end{array}$ & $\begin{array}{l}6 \\
6 \\
6\end{array}$ & $\begin{array}{l}-2982.10 \\
-2981.89\end{array}$ & $\begin{array}{l}5972.26 \\
5973.86\end{array}$ & $\begin{array}{r}39.88 \\
41.49\end{array}$ & $\begin{array}{l}0 \\
0 \\
0\end{array}$ \\
\hline $\begin{array}{l}104 \\
100\end{array}$ & $\begin{array}{r}272501.27 \\
29916.08\end{array}$ & 0.045 & & & $\begin{array}{r}-0.05 \\
0.31\end{array}$ & & $\begin{array}{r}-25747.51 \\
-27838.28\end{array}$ & $\begin{array}{l}461.89 \\
320.06\end{array}$ & $\begin{array}{l}8 \\
7\end{array}$ & $\begin{array}{l}-2950.14 \\
-2951.30\end{array}$ & $\begin{array}{l}5916.49 \\
5916.76\end{array}$ & $\begin{array}{r}272501.27 \\
299116.08\end{array}$ & $\begin{array}{l}0 \\
0 \\
0\end{array}$ \\
\hline $\begin{array}{r}106 \\
62 \\
63\end{array}$ & $\begin{array}{l}274344.35 \\
271681.88\end{array}$ & $\begin{array}{l}0.015 \\
0.015\end{array}$ & $\begin{array}{r}30.35 \\
9.67 \\
9.70\end{array}$ & $\begin{array}{l}-20.65 \\
-20.64\end{array}$ & 0.37 & $\begin{array}{l}7 \\
8 \\
8\end{array}$ & $\begin{array}{l}-24843.91 \\
-24614.86\end{array}$ & & $\begin{array}{l}7 \\
8 \\
8\end{array}$ & $\begin{array}{r}-2951.47 \\
-2950.55\end{array}$ & $\begin{array}{l}5917.11 \\
5917.31\end{array}$ & $\begin{array}{l}274344.35 \\
271681.89\end{array}$ & $\begin{array}{l}0 \\
0\end{array}$ \\
\hline $\begin{array}{l}91 \\
90\end{array}$ & $\begin{array}{l}-10900.17 \\
276095.92\end{array}$ & & $\begin{array}{l}17.20 \\
17.20\end{array}$ & $\begin{array}{l}-16.15 \\
-16.14\end{array}$ & $\begin{array}{l}0.23 \\
0.23\end{array}$ & $\begin{array}{l}7 \\
7\end{array}$ & & 934.36 & $\begin{array}{l}9 \\
7 \\
7\end{array}$ & $\begin{array}{l}-2950 . / 2 \\
-2951.87 \\
-2951.88\end{array}$ & $\begin{array}{l}5917.65 \\
5917.90 \\
5917.92\end{array}$ & $\begin{array}{l}-18902.32 \\
-22400.17 \\
276095.92\end{array}$ & 0 \\
\hline $\begin{array}{r}42 \\
43 \\
407\end{array}$ & $\begin{array}{l}263527.11 \\
-11044.60 \\
-30322\end{array}$ & & $\begin{array}{l}29.19 \\
29.20 \\
30.36\end{array}$ & & 0.37 & $\begin{array}{l}6 \\
6 \\
7\end{array}$ & -23 & 489.74 & 6 & $\begin{array}{l}-2952.96 \\
-2953.11\end{array}$ & $\begin{array}{l}5918.04 \\
5918.33\end{array}$ & $\begin{array}{r}263527.10 \\
-11044.60\end{array}$ & $\begin{array}{l}0 \\
0\end{array}$ \\
\hline $\begin{array}{l}126 \\
114\end{array}$ & 277210.55 & 0.001 & 27.18 & $\begin{array}{r}-3.57 \\
-3567\end{array}$ & $\begin{array}{l}0.32 \\
0.04\end{array}$ & 9 & $\begin{array}{l}-25106.67 \\
-25567\end{array}$ & 1255.36 & 9 & -2950.20 & 5918.66 & 277210.55 & 0 \\
\hline $\begin{array}{l}127 \\
115\end{array}$ & $\begin{array}{l}-23703.63 \\
-21605.69\end{array}$ & 0.001 & 27.20 & $\begin{array}{r}-3.56 \\
-35.68\end{array}$ & $\begin{array}{l}0.32 \\
0.04\end{array}$ & $\begin{array}{l}9 \\
7\end{array}$ & .00 & $\begin{array}{l}989.63 \\
898.16\end{array}$ & $\begin{array}{l}9 \\
7\end{array}$ & $\begin{array}{l}-2950.31 \\
-2952.47\end{array}$ & $\begin{array}{l}5918.88 \\
5919.11\end{array}$ & $\begin{array}{l}-23703.63 \\
-21605.69\end{array}$ & $\begin{array}{l}0 \\
0\end{array}$ \\
\hline $\begin{array}{r}4 \\
24\end{array}$ & $\begin{array}{l}2995688.31 \\
332370.47\end{array}$ & -0.006 & & -16.36 & & $\begin{array}{l}5 \\
7\end{array}$ & $\begin{array}{l}-27113.37 \\
-27850.74\end{array}$ & $\begin{array}{r}-10.14 \\
-996.62\end{array}$ & $\begin{array}{l}5 \\
7\end{array}$ & $\begin{array}{l}-2954.88 \\
-2952.91\end{array}$ & $\begin{array}{l}5919.84 \\
5919.99\end{array}$ & $\begin{array}{l}8.31 \\
0.47\end{array}$ & $\begin{array}{l}0 \\
0\end{array}$ \\
\hline $\begin{array}{l}88 \\
54\end{array}$ & $\begin{array}{l}315888.55 \\
279769.29\end{array}$ & $\begin{array}{l}0.010 \\
0.015\end{array}$ & & $\begin{array}{l}-18.28 \\
-29.99\end{array}$ & -0.32 & $\begin{array}{l}8 \\
7\end{array}$ & $\begin{array}{l}-25905.85 \\
-25359.38\end{array}$ & 1191.93 & $\frac{8}{7}$ & $\begin{array}{l}-2952.33 \\
-2954.30\end{array}$ & $\begin{array}{l}5920.86 \\
5922.76\end{array}$ & $\begin{array}{l}315888.55 \\
279769.29\end{array}$ & $\begin{array}{l}0 \\
0\end{array}$ \\
\hline $\begin{array}{l}55 \\
31\end{array}$ & $\begin{array}{l}-17446.25 \\
-13942.84\end{array}$ & $\begin{array}{l}0.015 \\
0.014 \\
0.014\end{array}$ & $\begin{array}{l}15.23 \\
15.22\end{array}$ & $\begin{array}{l}-30.00 \\
-14.86 \\
-14.85\end{array}$ & & $\begin{array}{l}7 \\
7\end{array}$ & & $\begin{array}{l}730.48 \\
597.15\end{array}$ & $\begin{array}{l}7 \\
7\end{array}$ & $\begin{array}{l}-2954.33 \\
-2954.69\end{array}$ & $\begin{array}{l}5922.81 \\
5923.54\end{array}$ & $\begin{array}{l}-17446.25 \\
-13942.84\end{array}$ & $\begin{array}{l}0 \\
0\end{array}$ \\
\hline 68 & 325781.37 & 0.022 & 22.38 & & 0.06 & 6 & $\begin{array}{l}-2453.52 \\
-27829.57 \\
-24558.34\end{array}$ & -743.82 & $\begin{array}{l}1 \\
6 \\
7\end{array}$ & $\begin{array}{l}-2954 . / 2 \\
-2955.90\end{array}$ & 5923.92 & $\begin{array}{r}270854.87 \\
325781.37\end{array}$ & 0 \\
\hline 40 & $\begin{array}{r}2 \\
-13201.69\end{array}$ & $\begin{array}{l}0.022 \\
0.000\end{array}$ & $\begin{array}{l}22.40 \\
30.35\end{array}$ & & 0.37 & $\begin{array}{l}7 \\
8\end{array}$ & $\begin{array}{l}-24500.04 \\
-2495025\end{array}$ & 570.17 & 7 & -2955.08 & 5924.32 & -13201.69 & 0 \\
\hline 111 & -26910.22 & $\begin{array}{l}0.000 \\
0.018\end{array}$ & 30.36 & -30 & $\begin{array}{r}0.37 \\
-0.06\end{array}$ & $\begin{array}{l}8 \\
8 \\
8\end{array}$ & -24900.20 & 1118.8622 & 8 & -2954.67 & 5925.54 & -26910.22 & 0 \\
\hline $\begin{array}{l}94 \\
74\end{array}$ & $\begin{array}{l}276199.88 \\
291800.73\end{array}$ & 0.008 & $\begin{array}{l}17.14 \\
18.82\end{array}$ & $\begin{array}{l}-13.54 \\
-13\end{array}$ & $\begin{array}{r}-0.00 \\
0.18 \\
0.51\end{array}$ & $\begin{array}{l}8 \\
8 \\
6\end{array}$ & $\begin{array}{l}-25022.25 \\
-26446.31\end{array}$ & & $\begin{array}{l}8 \\
8 \\
6\end{array}$ & $\begin{array}{l}-2954.92 \\
-2954.93 \\
-2957.01\end{array}$ & $\begin{array}{l}5926.00 \\
5926.07 \\
5926.14\end{array}$ & $\begin{array}{l}276190.98 \\
291800.73\end{array}$ & $\begin{array}{l}0 \\
0 \\
0\end{array}$ \\
\hline $\begin{array}{r}15 \\
119\end{array}$ & $\begin{array}{l}-33145.66 \\
-19452.84\end{array}$ & 0.018 & 18.83 & -30.04 & $\begin{array}{r}0.51 \\
-0.06\end{array}$ & $\begin{array}{l}6 \\
8\end{array}$ & & $\begin{array}{l}1361.47 \\
811.256\end{array}$ & $\begin{array}{l}6 \\
8\end{array}$ & $\begin{array}{l}-2957.06 \\
-2955.16\end{array}$ & $\begin{array}{l}5926.23 \\
5926.52\end{array}$ & $\begin{array}{r}-33 \\
-194 \\
\end{array}$ & $\begin{array}{l}0 \\
0\end{array}$ \\
\hline $\begin{array}{l}95 \\
8\end{array}$ & $\begin{array}{l}-247511.41 \\
316805.57\end{array}$ & $\begin{array}{l}0.008 \\
0.015\end{array}$ & 17.14 & -13.55 & 0.18 & 8 & -27575.076 & $\begin{array}{r}1028.26 \\
-496.95\end{array}$ & $\begin{array}{l}8 \\
6 \\
6\end{array}$ & $\begin{array}{l}-2955.17 \\
-2957.37\end{array}$ & $\begin{array}{l}5926.55 \\
5926.87\end{array}$ & $\begin{array}{l}1.41 \\
5.57\end{array}$ & $\begin{array}{l}0 \\
0\end{array}$ \\
\hline 14 & 271730.53 & 0.032 & 15.44 & & -0.2 & 6 & $\begin{array}{l}-26 / 95.33 \\
-24616.62\end{array}$ & -1024.67 & 6 & 9.09 & $\begin{array}{l}5928.43 \\
5930.30\end{array}$ & $\begin{array}{l}321442.43 \\
271730.53\end{array}$ & $\begin{array}{l}0 \\
0\end{array}$ \\
\hline $\begin{array}{l}15 \\
10\end{array}$ & $\begin{array}{l}-16117.16 \\
281186.88\end{array}$ & & $\begin{array}{r}15.45 \\
9.74\end{array}$ & & & $\begin{array}{l}6 \\
5\end{array}$ & -25470.76 & 684.99 & $\begin{array}{l}6 \\
5\end{array}$ & 1.09 & $\begin{array}{l}5930.34 \\
5932.26\end{array}$ & $\begin{array}{l}-16177.16 \\
281186.88\end{array}$ & $\begin{array}{l}0 \\
0\end{array}$ \\
\hline $\begin{array}{l}11 \\
78\end{array}$ & $\begin{array}{l}-20325.76 \\
278806.29\end{array}$ & 0.022 & 17.89 & & 0.24 & 7 & -25263.12 & 853.36 & $\begin{array}{l}5 \\
7\end{array}$ & $\begin{array}{l}-2961.11 \\
-2959.10\end{array}$ & $\begin{array}{l}5932.31 \\
5932.36\end{array}$ & $\begin{array}{l}-20325.76 \\
278806.29\end{array}$ & $\begin{array}{l}0 \\
0\end{array}$ \\
\hline $\begin{array}{r}57 \\
79\end{array}$ & $\begin{array}{r}966.04 \\
-25398.24 \\
1\end{array}$ & 0.022 & 17.90 & -26.35 & 0.24 & $\begin{array}{l}6 \\
7\end{array}$ & & 1052.40 & $\begin{array}{l}6 \\
7\end{array}$ & $\begin{array}{l}-2960.13 \\
-2959.14\end{array}$ & $\begin{array}{l}5932.37 \\
5932.44\end{array}$ & $\begin{array}{r}966.04 \\
-25398.24\end{array}$ & $\begin{array}{l}0 \\
0\end{array}$ \\
\hline $\begin{array}{r}121 \\
18\end{array}$ & $\begin{array}{r}1046.35 \\
306451.75\end{array}$ & & & $\begin{array}{r}-2.15 \\
-13.34\end{array}$ & 0.3 & 5 & -27760.37 & & 5 & $\begin{array}{l}-2959.13 \\
-2962.01\end{array}$ & $\begin{array}{l}5933.62 \\
5934.10\end{array}$ & $\begin{array}{r}1046.35 \\
306451.75\end{array}$ & $\begin{array}{l}0 \\
0\end{array}$ \\
\hline $\begin{array}{l}15 \\
83 \\
82\end{array}$ & $\begin{array}{r}10698.68 \\
294752.23\end{array}$ & & & $\begin{array}{l}-13.34 \\
-21.62\end{array}$ & -0.26 & $\begin{array}{l}5 \\
6 \\
6\end{array}$ & -266 & $\begin{array}{l}-155.97 \\
-382.69\end{array}$ & 6 & $\begin{array}{l}-2962.25 \\
-2961.75\end{array}$ & $\begin{array}{l}5934.88 \\
5935.61\end{array}$ & $\begin{array}{r}498 \\
1069\end{array}$ & $\begin{array}{l}0 \\
0\end{array}$ \\
\hline $\begin{array}{l}38 \\
39\end{array}$ & $\begin{array}{r}291763.75 \\
-20852.77\end{array}$ & $\begin{array}{l}0.043 \\
0.043\end{array}$ & & & & $\begin{array}{l}6 \\
6\end{array}$ & -26 & 866.68 & 6 & -2962.22 & $\begin{array}{l}5935.73 \\
5936.56\end{array}$ & $\begin{array}{r}291763.75 \\
-20852.77\end{array}$ & $\begin{array}{l}0 \\
0\end{array}$ \\
\hline $\begin{array}{l}49 \\
25 \\
34\end{array}$ & $\begin{array}{r}860.09 \\
1013.94 \\
298322.05\end{array}$ & & 14.20 & $\begin{array}{l}-36.29 \\
-21.82\end{array}$ & & $\begin{array}{l}5 \\
5 \\
5\end{array}$ & -270 & & 5 & $\begin{array}{l}-2963.91 \\
-2964.23\end{array}$ & $\begin{array}{l}5937.89 \\
5938.54\end{array}$ & $\begin{array}{r}860.10 \\
1013.94\end{array}$ & $\begin{array}{l}0 \\
0 \\
0\end{array}$ \\
\hline $\begin{array}{r}35 \\
103\end{array}$ & $\begin{array}{r}-8139.32 \\
-13171.24\end{array}$ & 0.045 & & & -0.05 & $\frac{5}{7}$ & 270 & $\begin{array}{l}366.28 \\
559.88\end{array}$ & $\begin{array}{l}5 \\
7\end{array}$ & $\begin{array}{l}-2964.28 \\
-2962.43\end{array}$ & $\begin{array}{l}5938.65 \\
5939.02\end{array}$ & $\begin{array}{r}290139.32 \\
-13171.23 \\
-1317\end{array}$ & $\begin{array}{l}0 \\
0\end{array}$ \\
\hline $\begin{array}{r}102 \\
99\end{array}$ & $\begin{array}{l}288564.86 \\
-19352.05\end{array}$ & 0.045 & & & $\begin{array}{r}-0.05 \\
0.31\end{array}$ & $\begin{array}{l}7 \\
6\end{array}$ & -26158.09 & 809.93 & 7 & -2962. & $\begin{array}{l}5939.07 \\
593932\end{array}$ & 288564.86 & 0 \\
\hline $\begin{array}{r}98 \\
905\end{array}$ & 304864.91 & & & & $\begin{array}{l}0.31 \\
0.37\end{array}$ & $\begin{array}{l}0 \\
6 \\
6\end{array}$ & -27633.50 & & $\begin{array}{l}0 \\
6 \\
6\end{array}$ & $\begin{array}{r}-2963.61 \\
-2963.84\end{array}$ & $\begin{array}{l}5939.33 \\
5939.8\end{array}$ & 304864.91 & 0 \\
\hline $\begin{array}{l}61 \\
89\end{array}$ & $\begin{array}{r}918.54 \\
958.81\end{array}$ & 0.015 & $\begin{array}{r}9.70 \\
17.20\end{array}$ & $\begin{array}{l}-20.64 \\
-16.15\end{array}$ & 0.23 & $\begin{array}{l}7 \\
6\end{array}$ & & & $\begin{array}{l}7 \\
6\end{array}$ & $\begin{array}{l}-2962.92 \\
-2964.25\end{array}$ & $\begin{array}{l}5940.00 \\
5940.62\end{array}$ & $\begin{array}{l}91 \\
95\end{array}$ & $\begin{array}{l}0 \\
0 \\
0\end{array}$ \\
\hline $\begin{array}{r}41 \\
125\end{array}$ & $\begin{array}{l}1198.84 \\
1037.15\end{array}$ & 0.001 & $\begin{array}{l}29.20 \\
27.20\end{array}$ & -3.56 & 0.32 & 8 & & & 8 & $\begin{array}{l}-2965.32 \\
-2962.57\end{array}$ & $\begin{array}{l}5940.72 \\
5941.35\end{array}$ & $\begin{array}{l}1198.83 \\
1037.15\end{array}$ & 0 \\
\hline $\begin{array}{r}113 \\
22\end{array}$ & $\begin{array}{r}848.37 \\
312408.75\end{array}$ & -0.006 & & $\begin{array}{l}-35.68 \\
-16.36\end{array}$ & & $\begin{array}{l}6 \\
6\end{array}$ & -283 & & 6 & -2965.20 & $\begin{array}{l}5941.48 \\
5942.53\end{array}$ & 312408.75 & 0 \\
\hline 23 & $\begin{array}{r}306715.41 \\
5433.60\end{array}$ & -0.006 & & -16.37 & & 6 & & -173.48 & 6 & -2965.26 & $\begin{array}{l}5942.53 \\
5942.63\end{array}$ & $\begin{array}{r}306715.41 \\
5433.60\end{array}$ & 0 \\
\hline 86 & $\begin{array}{r}-2468.65 \\
292471.45\end{array}$ & 0.010 & & -18.28 & -0.32 & $\begin{array}{l}4 \\
7\end{array}$ & -26485.95 & & 7 & -29 & $\begin{array}{l}5942.75 \\
5943.53\end{array}$ & $\begin{array}{r}-2468.65 \\
292471.45\end{array}$ & 0 \\
\hline $\begin{array}{l}87 \\
53 \\
29\end{array}$ & $\begin{array}{r}12094.84 \\
815.84\end{array}$ & $\begin{array}{l}0.001 \\
0.015 \\
0.014\end{array}$ & 1523 & $\begin{array}{l}-18.29 \\
-30.00 \\
-14.86\end{array}$ & $033+3$ & $\begin{array}{l}7 \\
6 \\
6\end{array}$ & & -438.75 & $\begin{array}{l}7 \\
6\end{array}$ & $\begin{array}{l}-2964.91 \\
-2966.67\end{array}$ & $\begin{array}{l}5943.98 \\
5945.46\end{array}$ & $\begin{array}{r}12094.84 \\
815.84 \\
885\end{array}$ & 0 \\
\hline $\begin{array}{l}66 \\
67\end{array}$ & $\begin{array}{r}312159.70 \\
-1992.15\end{array}$ & & & & $\begin{array}{l}0.06 \\
0.06\end{array}$ & $\begin{array}{l}0 \\
5 \\
5\end{array}$ & -28281.74 & 122.11 & 5 & $\begin{array}{l}-2968.26 \\
-2968.32\end{array}$ & $\begin{array}{l}5946.60 \\
5946.73\end{array}$ & $\begin{array}{r}31215 \\
-199\end{array}$ & $\begin{array}{l}0 \\
0\end{array}$ \\
\hline $\begin{array}{r}45 \\
109\end{array}$ & $\begin{array}{l}1052.61 \\
1061.34\end{array}$ & $\begin{array}{l}0.022 \\
0.000\end{array}$ & $\begin{array}{l}22.40 \\
30.36\end{array}$ & & 0.37 & $\begin{array}{l}6 \\
7\end{array}$ & & & $\frac{0}{7}$ & & 5947.79 & $\begin{array}{l}1052.61 \\
1061.34\end{array}$ & 0 \\
\hline $\begin{array}{r}117 \\
93 \\
\end{array}$ & $\begin{array}{l}828.56 \\
955.00\end{array}$ & $\begin{array}{l}0.018 \\
0.008\end{array}$ & 17.14 & $\begin{array}{l}-30.04 \\
-13.55\end{array}$ & $\begin{array}{r}-0.06 \\
0.18\end{array}$ & $\begin{array}{l}7 \\
7\end{array}$ & & & $\begin{array}{l}7 \\
7\end{array}$ & $\begin{array}{l}-2967.30 \\
-2967.30\end{array}$ & $\begin{array}{l}5948.75 \\
5948.77\end{array}$ & $\begin{array}{l}828.56 \\
955.00\end{array}$ & 0 \\
\hline $\begin{array}{r}3 \\
6 \\
7\end{array}$ & $\begin{array}{r}891.10 \\
308032.60\end{array}$ & 0.014 & & & & $\begin{array}{l}5 \\
5\end{array}$ & -27906.96 & & 5 & -2969.73 & 5949.54 & $\begin{array}{r}891.10 \\
308032.60\end{array}$ & $\begin{array}{l}0 \\
0\end{array}$ \\
\hline 71 & $\begin{array}{r}2341.94 \\
10037.28\end{array}$ & $\begin{array}{l}0.014 \\
0.030\end{array}$ & & & -0.2 & $\begin{array}{l}5 \\
6\end{array}$ & & $\begin{array}{r}-51.44 \\
-358.41\end{array}$ & 6 & -2969.50 & $\begin{array}{l}5950.24 \\
5951.12\end{array}$ & $\begin{array}{r}2341.94 \\
10037.28\end{array}$ & 0 \\
\hline $\begin{array}{l}70 \\
13 \\
9\end{array}$ & $\begin{array}{r}297914.29 \\
947.57\end{array}$ & $\begin{array}{l}0.030 \\
0.032\end{array}$ & $\begin{array}{r}15.45 \\
9.75\end{array}$ & & $=0$ & $\begin{array}{l}6 \\
5\end{array}$ & -26985.19 & & $\begin{array}{l}6 \\
5\end{array}$ & $\begin{array}{l}-2969.52 \\
-2971.46\end{array}$ & $\begin{array}{l}5951.15 \\
5953.00\end{array}$ & $\begin{array}{r}297914.29 \\
947.57\end{array}$ & $\begin{array}{l}0 \\
0\end{array}$ \\
\hline $\begin{array}{l}77 \\
17\end{array}$ & 911.84 & 0.022 & 17.90 & & 0.24 & $\begin{array}{l}4 \\
6 \\
4\end{array}$ & & & 6 & -2971.49 & $\begin{array}{l}5954.9 / \\
5955.06\end{array}$ & $\begin{array}{r}1008.31 \\
911.84\end{array}$ & 0 \\
\hline $\begin{array}{l}11 \\
81 \\
37\end{array}$ & $\begin{array}{r}113.55 \\
814.24\end{array}$ & 0043 & & $\begin{array}{l}-13.34 \\
-21.62\end{array}$ & -0.26 & $\begin{array}{l}4 \\
5 \\
5\end{array}$ & & & 5 & -2974.10 & $\begin{array}{l}5956.83 \\
5958.29\end{array}$ & & 0 \\
\hline $\begin{array}{r}31 \\
33 \\
101\end{array}$ & $\begin{array}{r}1017.69 \\
102568\end{array}$ & 0.043 & & & & 4 & & & $\begin{array}{l}5 \\
4\end{array}$ & & $\begin{array}{l}5958.45 \\
5961.30\end{array}$ & $\begin{array}{r}814.24 \\
1017.67\end{array}$ & \\
\hline $\begin{array}{r}01 \\
97\end{array}$ & $\begin{array}{l}825.68 \\
896.32\end{array}$ & 0.045 & & & $\begin{array}{r}-0.05 \\
0.31\end{array}$ & $\begin{array}{l}6 \\
5\end{array}$ & & & $\begin{array}{l}6 \\
5\end{array}$ & $\begin{array}{l}-2974.79 \\
-2975.98\end{array}$ & $\begin{array}{l}5961.70 \\
5962.05\end{array}$ & $\begin{array}{l}825.68 \\
896.32\end{array}$ & $\begin{array}{l}0 \\
0\end{array}$ \\
\hline 21 & 1096.59 & -0.006 & & -16.37 & & $\begin{array}{ll}5 \\
3\end{array}$ & & & $\begin{array}{l}5 \\
3\end{array}$ & -2977.58 & 5965.24 & 1096.59 & 0 \\
\hline $\begin{array}{l}85 \\
65\end{array}$ & 1125.98 & 0.010 & & -18.29 & -0.32 & $\begin{array}{l}0 \\
6 \\
4\end{array}$ & & & $\begin{array}{l}0 \\
4\end{array}$ & $\begin{array}{l}-2977.06 \\
-298064\end{array}$ & $\begin{array}{l}5966.23 \\
596934\end{array}$ & $\begin{array}{l}1125.98 \\
1060.48\end{array}$ & 0 \\
\hline $\begin{array}{r}5 \\
69 \\
\end{array}$ & $\begin{array}{l}1055.91 \\
1077.05 \\
\end{array}$ & $\begin{array}{l}0.014 \\
0.029 \\
\end{array}$ & & & -0.27 & & & & 5 & $\begin{array}{l}-2982.10 \\
-2981.89 \\
\end{array}$ & $\begin{array}{l}5972.26 \\
5973.86 \\
\end{array}$ & $\begin{array}{l}1055.91 \\
1077.05 \\
\end{array}$ & 0 \\
\hline
\end{tabular}

